\title{
Alien amphipods (Arthopoda; Crustacea) in the Tista Estuary, Halden, southeastern Norway
}

\author{
Ingvar Spikkeland' and Jens Petter Nilssen²
}

\begin{abstract}
Spikkeland I and Nilssen JP. 2021. Alien amphipods (Arthopoda; Crustacea) in the Tista Estuary, Halden, southeastern Norway. Fauna norvegica 41: 34-40.

Two new amphipods for Norway Melita nitida and Corophium multisetosum (Crustacea; Amphipoda) were registered in brackish waters in the Tista Estuary in Halden, southeastern Norway. Both species were found in the samples from Tista's outlet into the Idde Fjord, C. multisetosum in the beach zone and M. nitida at about $4 \mathrm{~m}$ depth. Melita nitida is a North American species first found in Europe in the Netherlands in 1998, and since then dispersed into the Baltic Sea via the Kiel Canal and now also found several places on the German Baltic Sea coast and in the Black Sea. Corophium multisetosum was collected even before the 1920s in Western Europe, and is considered native for Europe, whereas its relationship to North America is more ambiguous. From the British Isles and the Netherlands, it seems to have spread to Germany, Poland, Denmark and Sweden, and at present Norway. Until now the two species were found in small numbers at the Norwegian sites and their influence on the total benthic community is probably negligible in this initial phase. The Tista Estuary in Halden apparently appears to be a hotspot for alien brackish water species in Norway. Generally estuaries, with their combination of brackish water jointly with their unsaturated ecological niches and intensive international ship traffic, seem to possess the highest potential infection rate for aquatic systems with alien macrozoobenthic species.
\end{abstract}

doi: 10.5324/fn.v4li0.3957. Received: 2021-02-02. Accepted: 2021-06-17. Published online: 2021-11-26. ISSN: $1891-5396$ (electronic).

Keywords: Melita nitida, Corophium multisetosum, Amphipoda, non-indigenous species (NIS), Norway

1. Østfold Museum Foundation, Dep. Haldenvassdragets Kanalmuseum, P.O. Box 64, NO-1871 Ørje, Norway 2. Müller-Sars Society for Free Basic Research, P.O. Box 170, NO-4952 Risør and Müller-Sars Biological Station, P.O. Box 64, NO-1871 Ørje, Norway

Corresponding author: Ingvar Spikkeland

E-mail: ingvar.spikkeland@ostfoldmuseene.no

\section{INTRODUCTION}

In Norway, approximately 2000 species of crustaceans (Arthropoda; Crustacea) are listed. The vast majority of these inhabit salt and brackish waters, while 240 species are registered in fresh water and 25 species are fully terrestrial (Oug et al. 2015). Due to Norway's distant location northwest in the European continent, and the fact that it was totally covered by glaciers several times during the Pleistocene, the numbers of freshwater species are generally low. Most freshwater organisms in Norway have immigrated from the Baltic Sea area subsequent to the Ice Age, but due to a varied and steep topography, many Central European species have not managed to spread here. This is especially true in western and northern Norway, except for the northeastern parts (Finnmark) which possesses relatively low relief landscape topography. Norway's relatively remote location has also meant that few foreign and invasive freshwater and brackish water species have found their way here in recent years compared to e.g. Central Europe, where especially many Ponto-Caspian species have established themselves during the last decades.

Over the past 15 years, however, several new crustacean species have been identified in Norwegian lakes, rivers and estuaries that have obviously been introduced in connection with human activities. Signal crayfish Pasifastacus leniusculus (Dana, 1852) was registered as a new species in Norway during 2006 (Johnsen et al. 2007), the isopod Proasellus coxalis (Dollfus, 1892) in 2013 (Spikkeland et al. 2013), and the related species Proasellus meridianus (Racowitza, 1919) in 2018 (Kemp et al. 2020). The amphipods Crangonyx pseudogracilis Bousfield, 1958 and Gammarus tigrinus Sexton, 1939 were detected for the first time in 2013 and 2018, respectively (Spikkeland et al. 2016, Spikkeland et al. 2020). Both the signal crayfish and the two amphipods originate from North America, while Proasellus coxalis is originally from the Mediterranean region, and Proasellus meridianus from westcentral and western Europe. Apart from the hydroid Cordylophora caspia (Pallas, 1771), the wave of Ponto-Caspian species that have reached and established themselves in Central Europe and the Baltic region during the last decades has so far not reached Norway.

In this study we report two new crustacean species for Norway, both collected in brackish water in the Tista Estuary in Halden, southeastern Norway; the North American amphipod Melita nitida Smith, 1873 and the probably native European species Corophium multisetosum Stock, 1952. 


\section{MATERIAL AND METHODS}

The Tista River constitutes the lower part of the Halden watercourse, and extends $4 \mathrm{~km}$ from Tistedal Town to the Idde Fjord (Figure 1). Downstream of the Tistedalsfoss waterfall, there are locks at Skonningsfoss and Porsnes, but these locks are now shut. The river downstream Porsnes Locks is influenced by saline water from the Idde Fjord, and quite polluted from industrial and sewage drains, but has been cleaner during the recent decades due to purification measures. Above the locks the main river is characterized by low levels of electrolytes (conductivity $5.5-8.0 \mathrm{mS} / \mathrm{m}$ ), although it is moderately polluted by runoff from agriculture, especially in the northern part of the Halden watercourse. At the river outlet/estuary, the salinity was measured to $4.8 \mathrm{ppt}$ in September 2018 and $4.3 \mathrm{ppt}$ in September 2020.

The benthic fauna of the Tista Estuary was studied at a site close to the river outlet in 2018 and 2020 (Figure 1). Animals living at 3-5 m depth were sampled 13 September 2018 using a boat and a bottom trawl designed for sampling bottom dwelling glacial relict crustaceans. Furthermore, the benthic fauna along the shore $(0-50 \mathrm{~cm})$ was sampled at 18 September 2018 and 30 September 2020. Along the shore, the bottom substrate, mainly stones, gravel and detritus, was kicked up and animals silted off by a hand net (sieve size $1 \mathrm{~mm}$ ). The net was also used for scratching macrophytes and soft bottom. Stones and other bottom material were also examined, and animals picked off by hand. There also exist five samples of the benthic fauna from September 1998, sampled by students at Östfold College, Halden. The exact locations of these samples are not known, but all are from the part of the river influenced by saline water or from the estuary. The sampling methods used in 1998 were only qualitative, while the methods used in 2018 were semi-quantitative, and thus give some information on the abundance of the different species. The material was kept in 75 percent ethanol. The amphipod species are determined by using the keys and descriptions of Stock (1952), Zettler \& Zettler (2017) and Vader \& Tandberg (2019). Specimens are deposited in the collections at Natural History Museum, University of Oslo (No. NHMO-F24816 - NHMO-F24830).

\section{RESULTS AND DISCUSSION}

The crustacean association in the Tista River and Estuary

In Table 1, crustaceans found in the Tista Estuary in September 2018 and 2020 are shown. Among the 14 species recorded, two were new to Norway: Melita nitida Smith, 1873 and Corophium multisetosum Stock, 1952. Only one female specimen of each these two species was found in 2018, C. multisetosum in the beach zone (Site 1a) and M. nitida at about $4 \mathrm{~m}$ depth (Site $1 \mathrm{~b})$. None of these species were recorded in the samples from 1998. Another Corophiidae species, Monocorophium insidiosum (Crawford, 1937), was recorded in large number at the river outlet (Site $1 \mathrm{~b}$ ), at a depth of 3-5 $\mathrm{m}$. This species has previously been recorded further out in the Idde Fjord in which the Tista River drains (Afzelius 1975). In September 2020, 26 specimens of Corophium multisetosum were detected at Site la. Five of these were ovigerous females or females with developed marsupium, one was a male and the rest juveniles, indicating that the species now is well established in the estuary. No samples were taken at Site $1 \mathrm{~b}$ in 2020. We therefore do not know how the population of Melita nitida has developed.

The invasive amphipod Gammarus tigrinus was also detected in this study, as the first discovery in Norway (Spikkeland et al. 2020). Other invasive alien species recorded in this study are the New Zealand mud snail Potamopyrgus antipodarum (Gray, 1843) and the bay barnacle Amphibalanus improvisus (Darwin, 1854). Furthermore, the brackish/freshwater hydroid Cordylophora caspia and the Chinese mitten crab Eriocheir sinensis H. Milne Edwards, 1853 has been recorded in the Idde Fjord (Afzelius \& Hardeng 1995, Spikkeland 2014, Jørn Bøhmer Olsen pers. comm.).

\section{The two alien crustaceans - ecology and identification Melita nitida Smith, 1873}

Melita nitida (Figure 2) is indigenous to the Atlantic coast of North America, from the Gulf of Saint Lawrence to the Yucatan Peninsula (Bousfield 1973). It has also been found at the Pacific coast in North America, probably introduced by man. In Europe M. nitida was first recorded in the Western Scheldt Estuary in the Netherlands in 1998 (Faasse and Moorsel 2003). However, re-examination of samples from

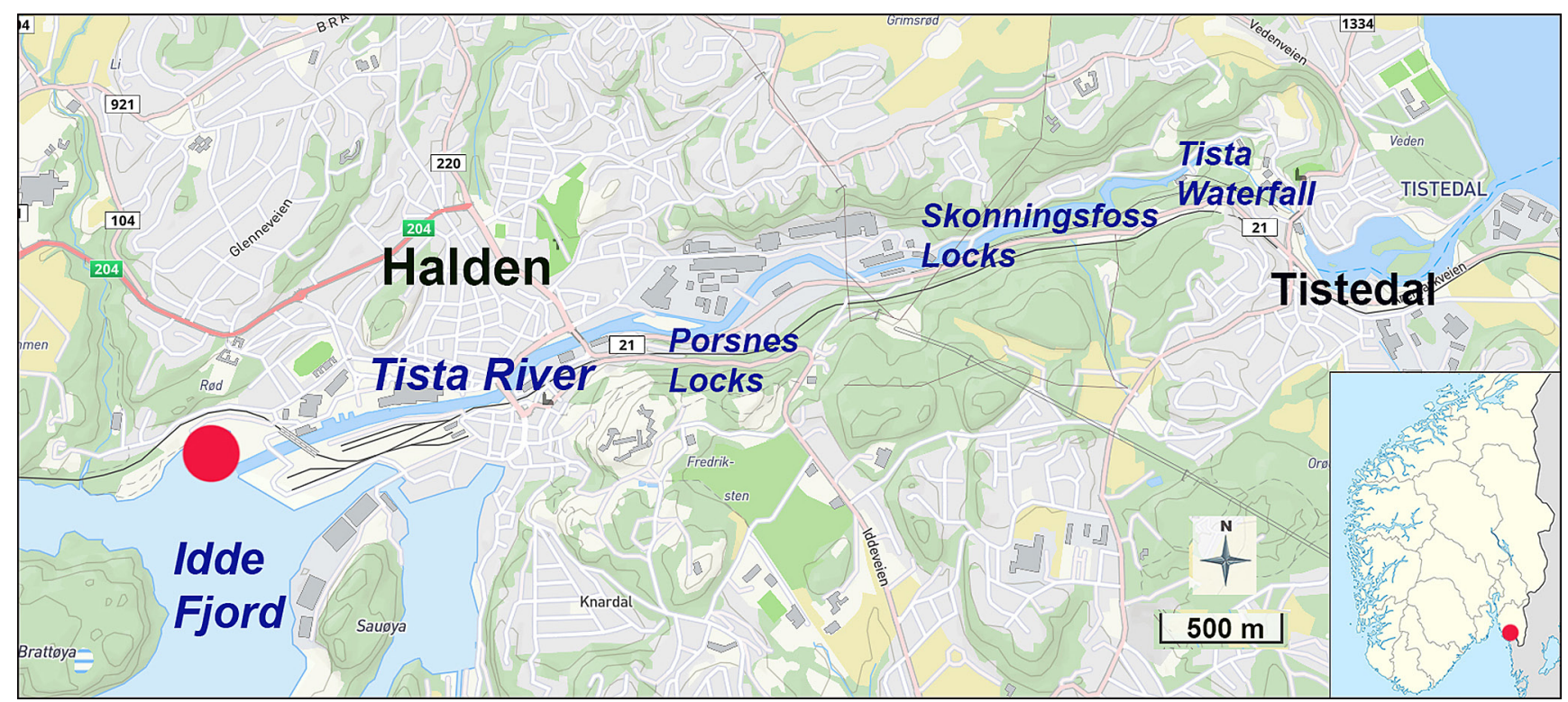

Figure I. Tista River in Halden, south-eastern Norway. The sampling site is marked with a red circle. (Underlying map: ( 2020 Norkart AS/ Geovekst og kommunene/NASA, Meti (C) Mapbox (C OpenStreetMap). 
Table I. Bentic crustacean species recorded in Tista Estuary in September 2018 and 2020. Site 1a: Shore $(0-50 \mathrm{~cm})$, Site 1b: Bottom $(3-5 \mathrm{~m})$. Geographic position (EU89): N 59,119, E 11,368.

\begin{tabular}{lccc}
\hline & 2018 & \multicolumn{2}{c}{2020} \\
\cline { 2 - 5 } Crustacean species & $1 \mathrm{a}$ & $1 \mathrm{a}$ & $1 \mathrm{~b}$ \\
\hline Asellus aquaticus (Linnaeus, 1758) & & & 1 \\
Heterotanais oerstedi (Krøyer, 1842) & 3 & & \\
Gammarus duebeni Lilljeborg, 1852 & 21 & 20 & \\
Gammarus salinus Spooner, 1947 & 6 & & \\
Gammarus tigrinus Sexton, 1939 & 22 & 72 & 3 \\
Gammarus zaddachi Sexton, 1912 & 12 & 4 & \\
Gammarus spp. (juvenile) & 70 & 444 & \\
Melita nitida Smith, 1873 & & & 1 \\
Corophium multisetosum Stock, 1952 & 26 & 1 & \\
Monocorophium insidiosum (Crawford, 1937) & & 1 & 72 \\
\hline Neomysis integer (Leach, 1814) & 75 & & \\
Palaemon adspersus Rathke, 1837 & & 12 & \\
\hline Athanas nitescens (Leach, 1814) & & 7 & \\
Crangon crangon (Linnaeus, 1758) & 11 & & \\
Carsinus maenas (Linnaeus, 1758) & 1 & 3 & \\
\hline
\end{tabular}

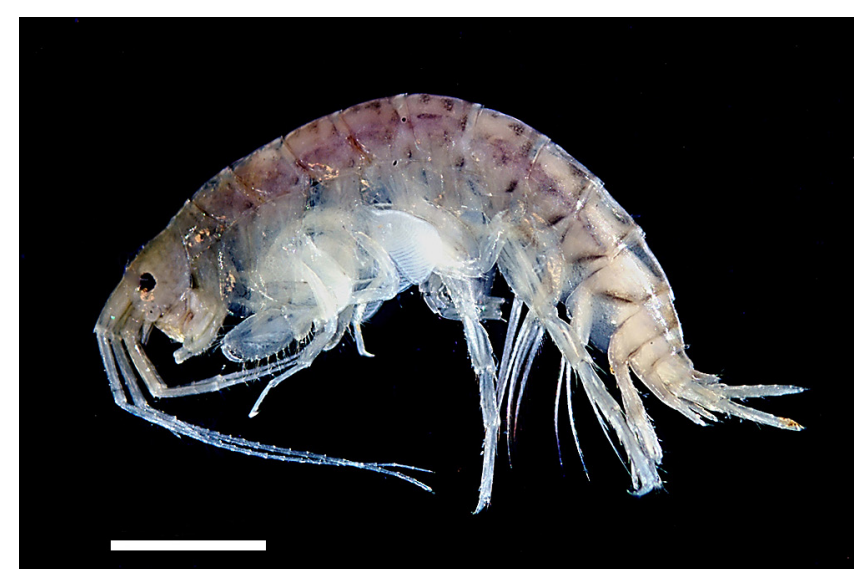

Figure 2. Melita nitida, female from Tista Estuary. Scale bar: $1 \mathrm{~mm}$. (Photo: Ingvar Spikkeland).

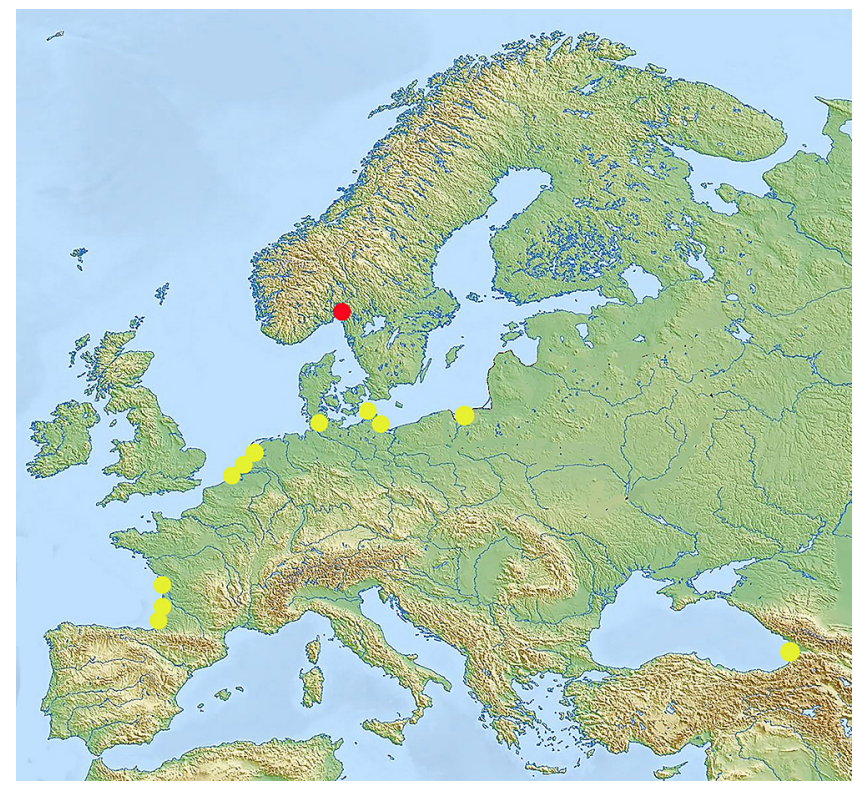

Figure 3. The present occurence of Melita nitida in Europe. (Underlying map: Wikipedia Commons). the nearby Belgian Zeeschelde revealed that the species lived there in 1996 (VLIZ Alien Species Consortium 2011).The species has later been reported from the North Sea Canal near Amsterdam and from The New Waterway connecting the Rhine with Rotterdam (Reichert \& Beermann 2011). In 2002 it was recorded in the Kiel Kanal (Reichert \& Beermann 2011), with subsequent finds in brackish water bays and lagoons in the German part of the Baltic Sea (Zettler \& Zettler 2017, Messner \& Zettler 2018). Between 2013 and 2016 Melita nitida was recorded in three different locations in SW France (Gouillieux et al. 2016), and in 2014 it was reported from the Gulf of Gdansk, Poland (Normant-Saremba et al. 2017). In 2019 the species was recorded for the first time in the Black Sea (Copilas-Ciocianu et al. 2020). The present occurrence in Europe is showed in Figure 3.

M. nitida can be distinguished from native Melita species by the following characters (Reichert \& Beermann 2011, Zettler \& Zettler 2017):

- Absence of dorsal teeth on pleosomites and urosomites (Figure $4 \mathrm{~A})$.

- Only urosomite 2 with a group of posterior, dorso-lateral spines on either side (Figure 4A).

- Accessory flagellum with at least 2 segments (Figure 4B).

- Male antenna 2 with prominent "bottle brush" setation on flagellum and distal parts of the peduncular article 5 .

The indigenous species Allomelita pellucida (G. O. Sars, 1882) can be confused with $M$. nitida, but differs from this species in the accessory flagellum (only 1 segment) and in the urosome spination.

In its original distribution area in North America, Melita nitida prefers muddy sediments in mesohaline regions of estuaries (salinity 3-20) but can occasionally be found at salinities up to $30 \mathrm{psu}$ (Bousfield 1973). It often lives in fouling communities and on oyster reefs, and in connection with epibenthic structures like hydroids and bryozoans (Zettler \& Zettler 2017). It also seems to be tolerant of low oxygen episodes (Sagasti et al. 2000). Whether a successful establishment of a

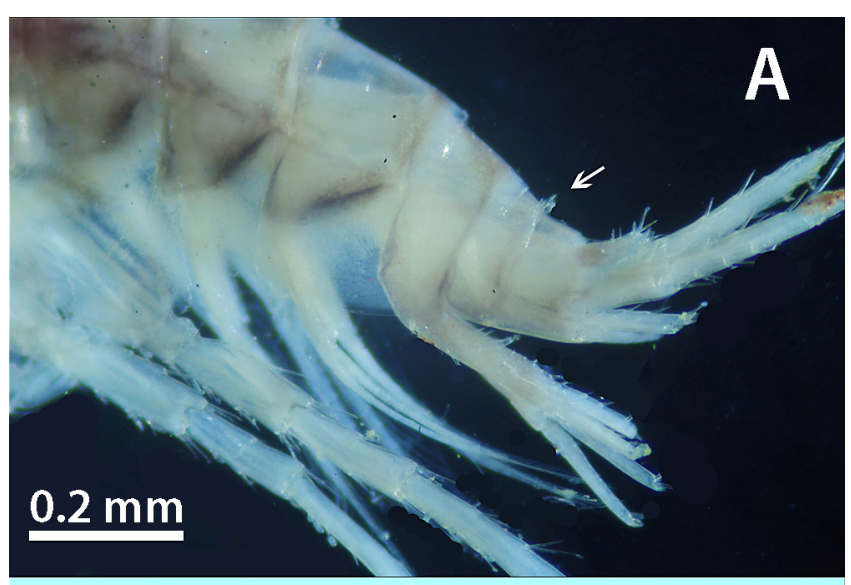

B

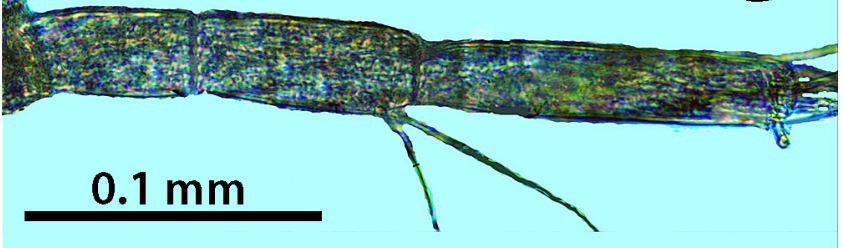

Figure 4. Anatomical characteristics of Melita nitida. A: Absence of dorsal teeth on pleosomites and urosomites, and urosomite 2 with a group of posterior, dorso-lateral spines on either side. B: Accessory flagellum with 3 segments. (Photos: Ingvar Spikkeland). 
population of Melita nitida will occur in the Tista Estuary depends on the general suitability of the habitat. The establishment of the species in Northeast Pacific estuaries indicate that low temperature will not be a limiting factor to the species in Norway, at least not in the southern part, and we expect the species to spread further to other estuaries in South Norway.

In the Netherlands, the invasive Melita nitida has almost completely replaced the native amphipod Melita palmata (Montagu, 1804) over the entire estuarine gradient of the Western Scheldt including the polyhaline zone where $M$. nitida was recorded for the first time in 2015. Melita palmata is also found in the Oslofjord area (Artsdatabanken), of which the Idde Fjord is a part and the invasive Melita nitida can therefore pose a threat to native Melita palmata in this area as well.

\section{Corophium multisetosum Stock, 1952}

Corophium multisetosum (Figure 5) has been found in several estuaries and water bodies in Europe ranging from fresh and brackish to salt water. It was recorded already in the 1904 in UK and in the

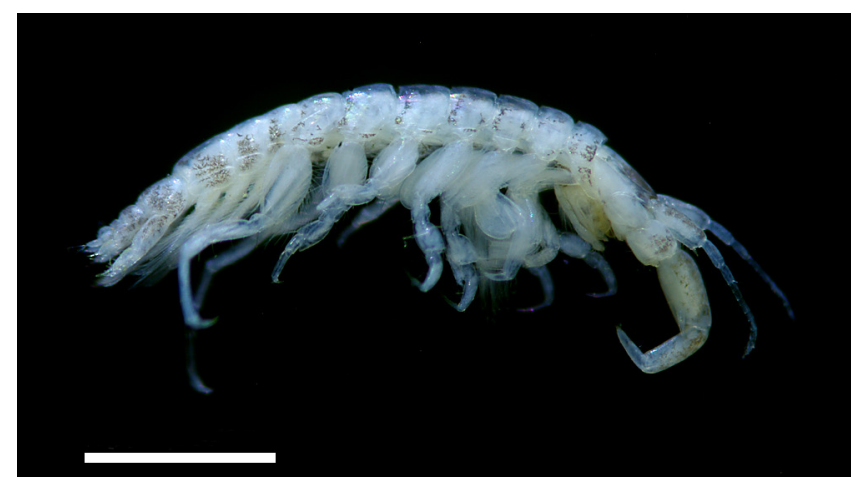

Figure 5. Corophium multisetosum, female from Tista Estuary. Scale bar: $1 \mathrm{~mm}$. (Photo: Ingvar Spikkeland).

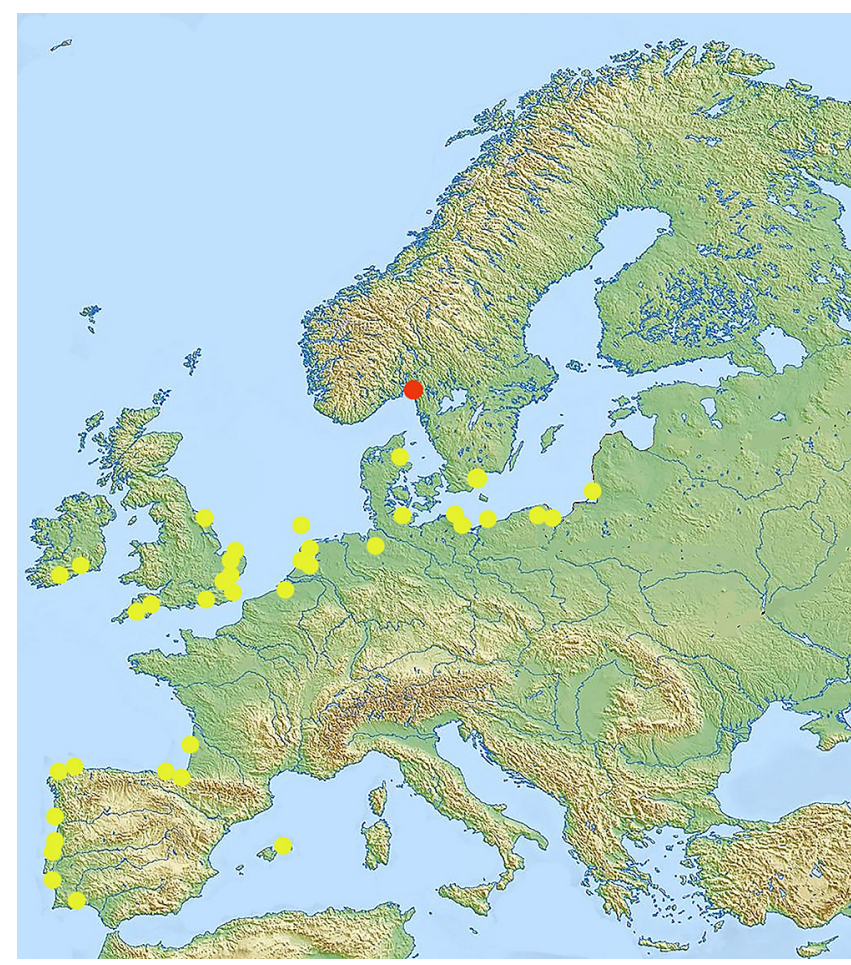

Figure 6. The present occurence of Corophium multisetosum in Europe. The exact location of the swedish occurence is not stated in Dyntaxa (2020). (Underlying map: Wikipedia Commons). 1920s in the Netherlands. The species appears to be distributed over a wide geographic range from the Iberian Peninsula to the southern Baltic region (Wijnhoven et al. 2011), in the latter region it was found for the first time in 1962 in a brackish water basin in Poland (Jażdżewski 1976). It is recently found in the Mediterranean and Gulf of Mexico, showing remarkable differences in ecology between populations, and is both referred to as a warm-water species in the Baltic and as a cold-water species in Portugal (Wijnhoven et al. 2011). In the Nordic countries, the species was reported from Denmark in 2002 (Wijnhoven et al. 2011), and from Sweden in 2013 (Dyntaxa 2020). It is nowadays considered an endemic species of the northeast Atlantic region (Buckley et al. 2004). Figure 6 shows the European distribution, based on information in Wijnhoven et al. (2011) and (Dyntaxa 2020).

The specimens in the Tista Estuary were sampled on a shallow beach with the bottom consisting of a mixture of mud, sand, gravel and rocks (Site 1a). The species builds mud burrows in muddy sands in fresh or weakly brackish habitats, and occasionally it constructs tubes on fixed substrata. It is a genuine brackish water species restricted to inner coastal waters such as estuaries and lagoons (Zettler \& Zettler 2017).

Corophium multisetosum can easily be confused with Corophium volutator (Pallas, 1866). In identification of our specimens, we have used the description and figures in Stock (1952) and Zettler \& Zettler (2017). Figure 7 shows different anatomical characteristics of the species sampled in the Tista Estuary that correspond well to the description of Corophium multisetosum and differ from C. volutator:

- The distolateral angle of uropod 3 peduncle is produced (Figure $7 \mathrm{~A})$.

- The telson apex is concave (Figure 7B). However, juvenile specimens in our material may have almost straight apex.

- In females the ventral margin of antennae 1 peduncle article 1 with 3 spines (Figure $7 \mathrm{C}$ ) and the inner margin with 1 or 2 proximal spines (Figure 7D)

- In both sexes the outer margin of uropod 1 peduncle with 7-8 spines, the inner edge with 2 (or 3) spines (Figure 7E).

- In both sexes uropod 2 peduncle has 3-4 dorsal spines and a prominent triangular projection (Figure 7F).

As far as further dispersal along the Norwegian coast is concerned, it depends on the degree to which the species is adapted to cold climate, as these areas are situated further north than other known occurrences of the species in Europe (Figure 6). Cunha et al. (2000a, b) showed that Corophium multisetosum had an optimal breeding temperature at $18^{\circ} \mathrm{C}$, with more intense breeding between 15 and $20^{\circ} \mathrm{C}$. The temperatures in the Tista Estuary will normally be in this interval during summer; sometimes even above $20^{\circ} \mathrm{C}$. Due to rising temperatures in recent decades, brackish waters along the southern part of the Norwegian coast probably will meet the species' environmental requirements to a successively greater degree.

\section{General discussion}

The Tista Estuary and the Idde Fjord - hot spot for alien species into Norway? The Tista Estuary, southeastern Norway, appears to be a hot spot for alien species into this country. If this concerns the whole fjord system of the Idde Fjord into which Tista drains or the estuary itself is unclear at the present state of knowledge. Moreover, geographically opposite of the Tista Estuary is the Enningdal Estuary, but this innermost estuary in the Idde Fjord has not been studied in detail during the last 20 years. In addition to the two alien crustacean species reported here, several taxa have been registered previously, such 


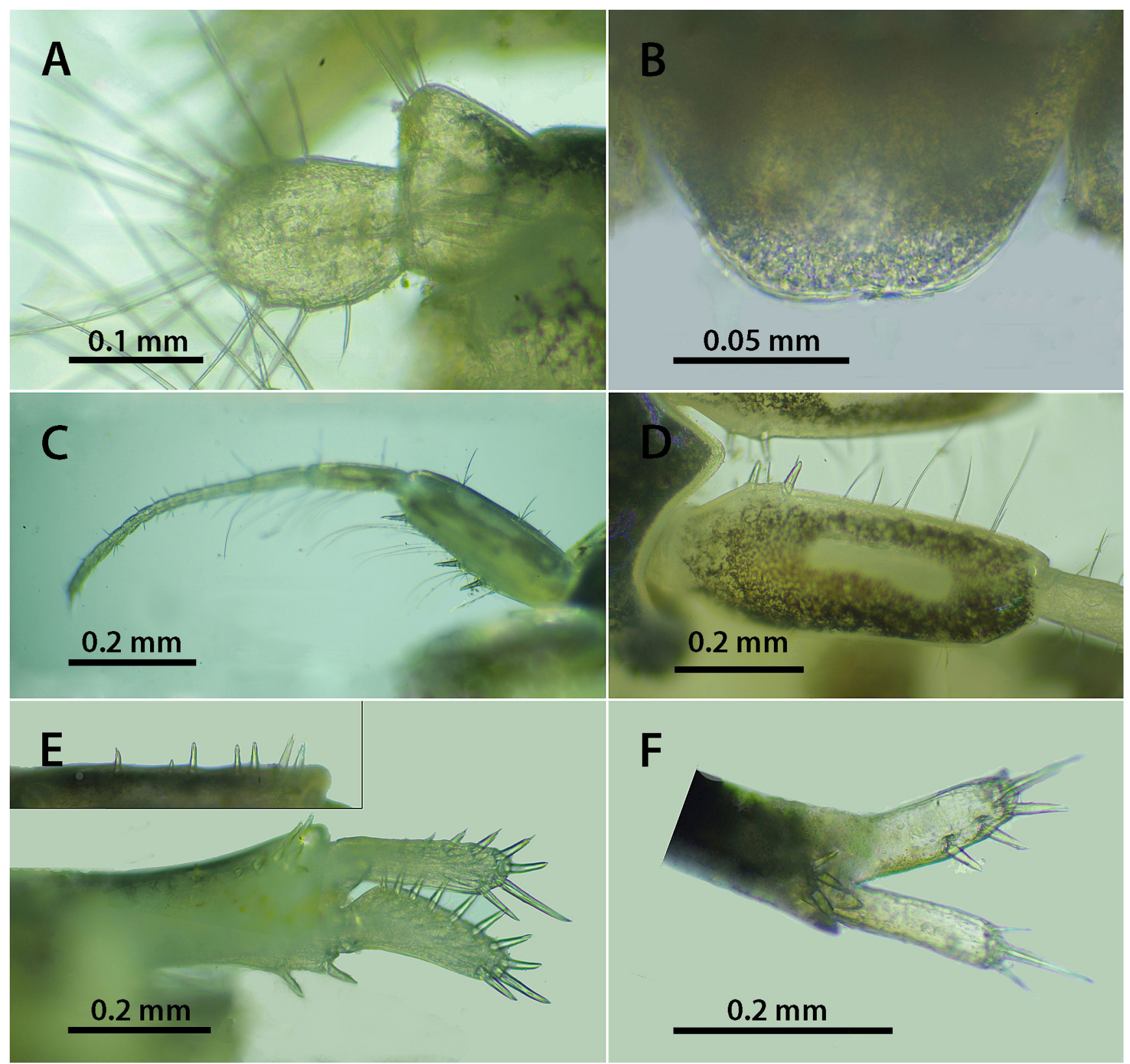

Figure 7. Anatomical characteristics of Corophium multisetosum. A: Uropod 3 peduncle with distolateral angle produced. B: The telson apex in adult specimens is concave. C: The ventral margin of antennae 1 peduncle article 1 with 3 spines (females). D: The inner margin of antennae 1 peduncle article 1 with 2 (or 1) proximal spines. E: The outer margin of uropod 1 peduncle with 7-8 spines, the inner edge with 2 (or 3) spines (both sexes). The inset image at the top shows the outer margin from a different angle with the spines visible. F: Uropod 2 peduncle with 3 (or 4 ) dorsal spines and a prominent triangular projection (both sexes). (Photos: Ingvar Spikkeland).

as the hydroid Cordylophora caspia (Hydrozoa), the New Zealand mud snail Potamopyrgus antipodarum (Gastropoda), the tiger scud Gammarus tigrinus (Amphipoda), the bay barnacle Amphibalanus improvisus (Cirripedia) and the Chinese mitten crab Eriocheir sinensis (Decapoda). About $4 \mathrm{~km}$ further out in the Idde Fjord, the Pacific oyster Crassostrea gigas (Thunberg, 1793) (Bivalvia) is also found.

The alien species mentioned above have probably been spread to the Tista Estuary/Idde Fjord with ballast water. Along the Idde Fjord there is a lot of granite, and the area has long been known for its granite quarries. Today, large quantities of granite are exported annually, especially to Denmark. Ballast water is released when the boats return, and although it is to be discharged into salt water off the Svinesund threshold, it is sometimes discharged in the Idde Fjord. There is also other shipping traffic to and from Halden Port (cf. www. marinetraffic.com:en:ais:details:ports:19096 :Norway_port/Halden).

\section{Estuaries and invasiveness}

Estuaries have been especially associated with aquatic invasions both worldwide as well as in Europe (Ruiz et al. 1997, Cohen and Carlton 1998, Wolff 1999, Nehring 2006). Based on studies on aquatic habitats in the Netherlands, Wolff (1999) formulated some main hypotheses for explaining the high figures of alien macroinvertebrates in Dutch estuaries, which was further supported by German studies by Nehring (2006). It was shown both for Dutch (Wolff 1999) as well as for German waters (Nehring 2006) that the brackish areas of estuaries have been invaded more frequently than rocky or sandy shores of the outer coast as well as inland waters by alien macroinvertebrate species. Generally, amphipods range among the most frequent and most intensive invading species (Grabowski et al. 2006, 2007a, 2007b, 2009, Jażdżewski \& Grabowski 2011).

It was further hypothesed (Wolff 1999, Nehring 2006) that estuaries with exhaustive transboundery shipping comprise a higher 
potential infection rate than most other aquatic zones. They also remarked (Wolff 1999, Nehring 2006) that brackish water species are exceptional due to their physiological characteristics and possessed a better chance of being transported alive compared to freshwater or high-saline species and probably also hold a higher establishment potential after release. They concluded (Wolff 1999, Nehring 2006) that brackish waters in addition often encompass a natural local species minimum which makes it easier for an introduced species to establish itself in such environments (e.g. Paavola et al. 2005). Consequently, the combination of brackish water with its unsaturated ecological niches and intensive international ship traffic has the highest potential infection rate for aquatic systems with alien macrozoobenthic species (Wolff 1999, Nehring 2006).

Biological invasions concern the successful establishment and spread of species outside their native range in the terrestrial, marine or freshwater ecosystems. The changes of the marine climate are a major component of global change and alien species are influenced by these changes to an extent we have just begun to perceive, observe and infer (Occhipinti-Ambrogi \& Galil 2010). Together with climate change also human activities, such as shipping, canal construction, aquarium trade and recreation are affecting species distribution locally and worldwide (e.g. Parmesan 2006). Human-assisted dispersal of nonnative species and the modification of natural habitats have generated widespread changes in the local and global distribution of organisms, and furthermore the widespread replacement of native species with cosmopolitan, non-native species is rapidly homogenizing the global fauna and flora (Olden \& Poff 2003, Olden et al. 2018, Clavel et al. 2010).

As far as further dispersal along the Norwegian coast of these two species Melita nitida and Corophium multisetosum is concerned, it depends on the degree to which the species is adapted to cold climate, as these areas are situated further north than other known occurrences of the species in Europe (Figure 5). Due to generally warmer climate during the last decades, brackish waters along the southern part of the Norwegian coast probably will be potential habitats for the species, and since they at present are ignored, they should be included in further studies.

\section{ACKNOWLEDGEMENT}

We are grateful to Gøran Brattstrøm for linguistic correction, to Jørn Bøhmer Olsen and Ragnar Kasbo for help during the field work, and to Norwegian Mapping Authority for permission to use map of Halden. We also want to thank the two reviewers for valuable comments and suggestions to an earlier draft of the manuscript.

\section{REFERENCES}

Afzelius L. 1975. Nasjonalt program for overvåkning av vannressurser. Utvikling og status i Iddefjordens biologi. [National Water Resources Monitoring Program. Development and status in the biology of the Iddefjord.]. NIVA-rapport O-75038. (In Swedish and Norwegian). 52 pp.

Artsdatabanken. Artskart. Artskart 2 (artsdatabanken.no). Accessed 2021-01-18.

Afzelius L, Hardeng G. 1995. Faunaen i Enningdalselva og Indre Iddefjord, med oversikt over naturfaglig litteratur. [The fauna in River Enningdalselva and the Inner Idde Fjord, with an overview of scientific literature]. (egian and Swedish). Rapport nr. 8. Fylkesmannen i Østfold. $39 \mathrm{pp}$.
Bousfield EL. 1973. Shallow-water Gammaridean Amphipoda of New England. Cornell Univ. Press, Ithaca \& London. 312 pp.

Buckley P, Dussart G, Trigwell J. 2004. Invasion and expansion of Corophiidae (Amphipoda) in the Stour estuary (Kent, UK). Crustaceana 77: 425-433.

Clavel J, Julliard R, Devictor V. 2010. Worldwide decline of specialist species: toward a global functional homogenization? Frontiers in Ecology and the Environment 8: 222-228. doi: 10.1890/080216.

Cohen AN, Carlton JT. 1998. Accelerating invasion rate in a highly invaded estuary. Science 279: 555-558. doi: 10.1126/science.279.5350.555.

Copilaş-Ciocianu D, Berchi GM, Mumladze L. 2020. First survey of shallow-water Amphipoda along the Georgian Black Sea coast reveals new faunistic records and the unexpected Atlantic invader Melita nitida. Mediterranean Marine Science 21(2): 460-463.

Cuhna MR, Sorbe JC, Moreira MH. 2000a. The amphipod Corophium multisetosum (Corophiidae) in Ria de Aveiro (NW Portugal). I. Life history and aspects of reproductive biology. Marine Biology 137: 637-650. doi: 10.1007/s002270000384.

Cuhna MR, Moreira HM, Sorbe JC. 2000b. Predicting amphipods' brood size variation in brackish environments: an empirical model for Corophium multisetosum Stock, 1952 (Corophiidae) in Ria de Aveiro (NW Portugal). Journal of Experimental Marine Biology and Ecology, 248: 207-223. doi: 10.1016/S0022-0981(00)00164-7.

Dyntaxa 2020. Corophium multisetosum. Svensk taxonomisk databas. [Swedish taxonomic database]. https://www.dyntaxa.se/Taxon/ Info/234280?changeRoot=True. Accessed 17/04/2020.

Faasse M, van Moorsel G. 2003. The North-American amphipods, Melita nitida Smith, 1873 and Incisocalliope aestuarius (Watling and Maurer, 1973) (Crustacea: Amphipoda: Gammaridea), introduced to the Western Scheldt estuary (The Netherlands). Aquatic Ecology 37: 13-22. doi: 10.1023/A:1022120729031.

Gouillieux B, Lavesque N, Blanchet H, Bachelet G. 2016. First record of the non-indigenous Melita nitida Smith, 1873 (Crustacea: Amphipoda: Melitidae) in the Bay of Biscay (NE Atlantic). BioInvasions Records 5 (2): 85-92. 10.3391/bir.2016.5.2.05.

Grabowski M, Konopacka A, Jażdżewski K, Janowska E. 2006. Invasion of alien gammarid species and retreat of natives in the Vistula Lagoon (Baltic Sea Poland). Helgolander Marine Research 60: 90-97. doi: 10.1007/s10152-006-0025-8.

Grabowski M, Bacela K, Konopacka A. 2007a. How to be an invasive gammarid (Amphipoda: Gammaroidea) - Comparison of life history traits. Hydrobiologia 590: 75-84. doi: 10.1007/s10750-007-0759-6.

Grabowski M, Jażdżewski K, Konopacka A. 2007b. Alien Crustacea in Polish waters - Amphipoda. Aquatic Invasions 2(1): 25-38. doi: 10.3391/ai.2007.2.1.3.

Grabowski M, Bacela K, Konopacka A, Jazdzewski K. 2009. Salinityrelated distribution of alien amphipods in rivers provides refugia for native species. Biol. Invasions 11:2107-2117. doi: 10.1007/s10530-0099502-8.

Jażdżewski K. 1976. Notes on the occurrence and ecology of Chaetogammarus stoerensis (Reid, 1938) and Corophium multisetosum Stock, 1952 (Amphipoda) in the Baltic Sea. Crustaceana 30 (1): $33-38$.

Jażdżewski K, Grabowski M. 2011. Alien Crustaceans along the Southern and Western Baltic Sea. Pp. 323-244 in: Galil BS, Clarck PF, Charlton JT. In the Wrong Place - Alien Marine Crustaceans: Distribution, Biology and Impacts. Invading Nature - Springer Series in Invasion Ecology, vol 6. Springer, Dordrecht. doi: 10.1007/978-94-007-05913 -11.

Johnnsen SI, Taugböl T, Andersen O, Museth J, Vrålstad T. 2007. The first record of the non-indigenous Signal Crayfish Pasifastacus leniusculus in Norway. Biol. Invasion 9: 939-941. doi: 10.1007/s10530-007-9092-2.

Kemp JL, Ballot A, Eriksen TE, Nilssen JP, Spikkeland I. 2020. Distribution, identification and range expansion of the common Asellidae in Northern Europe, featuring the first record of Proasellus meridianus in the Nordic countries. Fauna norvegica 40: 93-108. doi: 10.5324/fn.v40i0.3353. 
Messer U, Zettler ML. 2018. The conquest (or avoidance?) of the brackish environment by Ponto-Caspian amphipods: A case study of the German Baltic. Sea. BioInvasions records 7(3): 269-278. doi: 10.3391/ bir.2018.7.3.07.

Nehring S. 2006. Four arguments why so many alien species settle into estuaries, with special reference to the German river Elbe. Helgoland Marine Research 60(2):127-134. doi: 10.1007/s10152-006-0031-x.

Normant-Saremba M, Marszewska L, Kerckhof F. 2017. First record of the North American amphipod Melita nitida Smith, 1873 in Polish coastal waters. Oceanological and Hydrobiological Studies 46(1): 108-115. doi: 10.1515/ohs-2017-0011.

Occhipinti-Ambrogi A, Galil B. 2010. Marine alien species as an aspect of global change. Advances in Oceanography and Limnology 1(1): 199-218. doi: 10.1080/19475721003743876.

Olden JD, Poff NL. 2003. Toward a mechanistic understanding and prediction of biotic homogenization. The American Naturalist 162(4): 442-60. doi: 10.1086/378212.

Olden JD, Comte L, Giam X. 2018. The Homogocene: a research prospectus for the study of biotic homogenisation. NeoBiota 37: 23-36. doi: $10.3897 /$ neobiota.37.22552.

Oug E, Brattegard T, Walseng B, Djursvoll P. 2015. Krepsdyr (Crustacea). Norsk rødliste for arter 2015. [The Norwegian Red List 2015.] Artsdatabanken. http://www.artsdatabanken.no/Rodliste/ Artsgruppene/Krepsdyr. Accessed 4/12/2020.

Paavola M, Olenin S, Leppäkoski E. 2005. Are invasive species most successful in habitats of low native species richness across European brackish water seas? Estuarine Coastal and Shelf Science 64(4): 738-750. doi: 10.1016/j.ecss.2005.03.021.

Parmesan C. 2006. Ecological and evolutionary responses to recent climate change. Annual Review of Ecology, Evolution, and Systematics 37(1): 637-669. doi: 10.1146/annurev.ecolsys.37.091305.110100.

Reichert R, Beermann J. 2011. First record of the Atlantic gammaridean amphipod Melita nitida Smith, 1873 (Crustacea) from German waters (Kiel Canal). Aquatic Invasions 6: 103-108. doi: 10.3391/ai.2011.6.1.13.

Ruiz GM, Carlton JT, Grosholz ED, Hines AH. 1997. Global invasions of marine and estuarine habitats by non-indigenous species: Mechanisms, extent, and consequences. Integrative and Comparative Biology 37(6): 621-632. doi: 10.1093/icb/37.6.621.

Sagasti A, Schaffner LC, Duffy JE. 2000. Epifaunal communities thrive in an estuary with hypoxic episodes. Estuaries and Coasts 23(4): 474-487. doi: $10.2307 / 1353140$.

Spikkeland I. 2014. Biologisk mangfold i Haldenvassdraget. Om planter og dyr knyttet til vann i vassdragets nedbørfelt. Østfoldmuseene, avd. Haldenvassdragets Kanalmuseum. [Biodiversity in the Halden watercourse. Aquatic plants and animals in the river system] (In Norwegian). Østfoldmuseene, avd. Haldenvassdragets Kanalmuseum. Rapport 1/2014. 40 pp.

Spikkeland I, Nilssen JP, Kinsten B, Kjellberg G. 2013. En ny ferskvannsisopode Proasellus coxalis i Norge - ulovlig introdusert som følge av sports- eller mataukfiske? [A new freshwater isopod Proasellus coxalis in Norway - illegal introduction due to transboundary fishing?] (In Norwegian with English summary). Fauna 66: 54-62.

Spikkeland I, Olsen KM, Kinsten B, Kjellberg G. 2016. Ferskvannsamfipoden Crangonyx pseudogracilis påvist i Norge. [The freshwater amphipod Crangonyx pseudogracilis recorded in Norway.] (In Norwegian with English summary). Fauna 68 (3-4): 50-58.

Spikkeland I, Kasbo R, Böhmer Olsen J, Nilssen JP. 2020. The invasive amphipod Gammarus tigrinus Sexton, 1939 conquering the north of Europe using a new pathway: the first recordings from south Norway. Fauna norvegica 40: 130-136. doi: 10.5324/fn.v40i0.3582.

Stock JH. 1952. Some notes on the taxonomy, the distribution and the ecology of four species of the Amphipod genus Corophium (Crustacea, Malacostraca). Beaufortia 2 (21): 1-10.

Vader W, Tandberg AHS. 2019. Gammarid amphipods (Crustacea) in Norway, with a key to the species. Fauna Norvegica 39: 12-25. doi: 10.5324/fn.v39i0.2873.
VLIZ Alien Species Consortium 2011. Elegante honingvlokreeft - Melita nitida. Niet-inheemse soorten van het Belgisch deel van de Noordzee en aanpalende estuaria. [Elegant honey flea lobster - Melita nitida. Non-native species of the Belgian part of the North Sea and adjacent estuaries]. (In Flemish). VLIZ Information Sheets, 74. Vlaams Instituut voor de Zee (VLIZ): Oostende. 4 pp. (http://www.jpi-oceans.eu/imis? module $=$ ref\&refid $=210308 \&$ basketaction=add). Accessed 2021-01-09.

Wijnhoven S, van der Velde G, Hummel H. 2011. Is Corophium multisetosum Stock, 1952 an exotic invasive species in Europe? Distribution, habitat, and recent observations in the Netherlands. Crustaceana 84 (8): 975-1011. doi: 10.1163/001121611X579150.

Wijnhoven S. 2016. Non-indigenous species presence and distribution in intertidal hard substrate environments of the Western Scheldt: Results of Transect Monitoring inventory of 2016. Ecoauthor Report Series 2016-01. Heinkenszand, the Netherlands.

Wolff WJ. 1999. Exotic invaders of the meso-oligohaline zone of estuaries in the Netherlands: why are there so many? Helgoland Marine Research 52(3):393-400. doi: 10.1007/BF02908913.

Zettler ML, Zetter A. 2017. Marine and freshwater Amphipoda from the Baltic Sea and adjacent territories. ConchBooks. Harxheim. 845 pp.

Editorial responsibility: Anne Helene Tandberg.

This article is open-access and distributed under the terms of the Creative Commons Attribution 4.0 International license. This permits all noncommercial use, distribution, and reproduction in any medium, provided the original work is properly cited.

(http://creativecommons.org/licenses/by/4.0/). 